\title{
EFEKTIVITAS PIJAT OKSITOSIN TERHADAP PRODUKSI ASI
}

\author{
Hidayatun Nufus ${ }^{1}$ \\ ${ }^{1}$ STIKes Insan Cendekia Medika Jombang \\ 'email hidayatunnufus77@yahoo.com
}

\begin{abstract}
ABSTRAK
Tahun 2018 Jumlah kematian bayi sebanyak 199 bayi dari 19.353 Kelahiran Hidup, atau dengan kata lain angka AKB Kabupaten Jombang tahun 2018 sebesar 10 per $1.000 \mathrm{KH}$. Keberhasilan ini dikarenakan adanya beberapa pogram akselerasi AKB di jalankan dengan serius diantaranya adalah program IMD (inisiasi menyusui dini) dan ASI eksklusif. ASI bermanfaat untuk menjaga ketahanan tubuh bayi karena mengandung zat anti infeksi. Diharapkan semua ibu bisa memberikan ASI eksklusif pada bayinya, tetapi ketika saat kontrol hari ke $7,50 \%$ ibu sudah membawa botol dengan susu formula untuk bayinya. Oleh karenanya dibutuhkan usaha yang intensif untuk membantu ibu nifas normalagar menyusui bayinya, salah satunya dengan pijat oksitosin yang dapat membantu produksi ASI. Tujuan Penelitian ini adalah untuk mengetahui efektivitas pijat oksitosin terhadap produksi ASI pada ibu post partum normal. Metode penelitian ini menggunakan desain quasy eksperimenT dengan rancangan penelitian eksperimen semu atau dengan rancangan non randomized posttest without control group design. Pengambilan sampel dengan purposive sampling. Sampel berjumlah 50 orang ibu post partum normal yang dibagi dalam 2 kelompok, yaitu 25 responden pijat oksitosin dan 25 responden tanpa pijat oksitosin Hasil menunjukkan usia rata-rata ibu 20-35 tahun (92,5\%), multipara (70\%). Berdasarkan hasil analisis dengan uji statistik chi-square didapatkan bahwa nilai t hitung 9,22 > t tabel 3,84 dengan demikian Ho ditolak dan H1 diterima.Simpulan mayoritas produksi ASI pada ibu post partum normal adalah cukup dan ada perbedaan antara produksi ASI ibu post partum setelah mendapatkan pijat oksitosin dan tidak. Pijat oksitosin adalah salah satu cara untuk memperlancar dan meningkatkan produksi ASI. Pijat oksitosin merupakan salah satu contoh intervensi mandiri bidan dan dengan mudah dipilih dalam penatalaksanaan merangsang produksi ASI
\end{abstract}

Kata kunci : Pijat oksitosin, Produksi ASI

\section{EFFECTIVENESS OF OXYTOCIN MASSAGE ON ASI PRODUCTION}

\begin{abstract}
In 2018 the number of infant deaths was 199 out of 19,353 live births, or in other words the IMR rate for Jombang Regency in 2018 was 10/1,000 live birth. This success is due to some acceleration program IMR in the run of which is seriously IMD program (early initiation of breastfeeding) and exclusive breastfeeding. Breastfeeding is beneficial to maintain the resilience of the baby's body because it contains anti-infective agents. It is expected that all mothers can deliver their babies exclusively breastfed, but when when the control day 7 , $50 \%$ of mothers had brought a bottle with formula milk for babies. Therefore, intensive efforts are needed to help new mothers breastfeed their babies normal order, one of them with oxytocin massage can help breast milk production. The purpose of this study was to examine the effectiveness of massage oxytocin on milk production in mothers postpartum normal.This research method uses Quays design experiments with quasi-experimental research design or the non-randomized design without posttest control groupdesign. Sampling with purposive sampling. Samples of 50 people normal postpartum mothers who were divided into 2 groups, ie 25 massage respondents 25 respondents without oxytocin and oxytocin massage.The results showed the average age of mothers 20-35 years (92.5\%), multiparous (70\%). Based on the results of statistical analysis with the chi-square test
\end{abstract}


showed that $t$ value 9.22> t table 3.84 thus Ho is rejected and HI is accepted.Conclusion The majority of milk production in postpartum mothers is quite normal and there is a difference between postpartum maternal milk production after getting a massage and oxytocin. Massage oxytocin is one way to facilitate and increase milk production. Massage oxytocin is one example of an independent midwife and interventions easily been in treatment stimulates milk production.

Keywords: Massage Oxytocin, Milk Production

\section{PENDAHULUAN}

Tahun 2018 Jumlah kematian bayi sebanyak 199 bayi dari 19.353 Kelahiran Hidup, atau dengan kata lain angka AKB Kabupaten Jombang tahun 2018 sebesar 10 per $1.000 \mathrm{KH}$ Perawatan yang dilakukan pada awal kehidupan ditujukan untukmemenuhi kebutuhan dasar terutama kebutuhan fisiologis agar tercapai suatu keadaan yang stabil dan terbebas dari penyulit selama proses adaptasi, sehingga memungkinkan bayi untuk tumbuh dan berkembang secara optimal. Kebutuhan fisiologis itu seperti oksigen, nutrisi dapat berupa ASI, keseimbangan suhu tubuh, eliminasi, istirahat dan tidur. Angka keberhasilan menyusui khususnya secara eksklusif jelas meningkat di negara maju, tetapi hal ini belum terjadi di negara berkembang seperti Indonesia.

Air susu ibu (ASI) adalah cairan yang disekresikan oleh kelenjar payudara ibu berupa makanan alamiah atau susu terbaik bernutrisi dan berenergi tinggi yang diproduksi sejak kehamilan.

Pentingnya memberikan ASI secara eksklusif pada bayi baru lahir sampai usia 6 bulan dan terusmemberikan ASI sampai anak berusia 24 bulan telah memiliki bukti yang kuat.

ASI bermanfaat untuk menjaga ketahanan tubuh bayi karena mengandung zat anti infeksi. Penelitian yang dilakukan oleh Carina Venter dan Tara Dean pada tahun 2008, menyatakan bahwa ASI mengandung zat immune modulator serta zat gizi yang unik. Selain itu, ASI mengandung zat gizi lengkap seperti karbohidrat berupa laktosa, lemak yang banyak (asam lemak tak jenuh ganda), protein utama berupa lactabumin yang mudah dicerna, kandungan vitamin dan mineral yang banyak (Venter et al, 2008). Penyebab ibu tidak memberikan ASI secara eksklusif pada bayinya seperti ibuibu bekerja atau kesibukan social lainnya (Baskoro, 2008:74), faktor fisik ( kelainan endokrin, jaringan payudara hipoplastik, usia, nutrisi ), faktor reflek dan horman (prolaktin dan oksitosin) juga memegang peranan penting dalam laktasi, faktor psikologis (stress, kacau,marah dan sedih, kurangnya dukungan dan perhatian keluarga serta pasangan kepada ibu (Lawrence, 2004)), faktor sosial budaya (memasarkan susu formula), faktor ketidak mengertinya ibu tentang kolostrum (Baskoro, 2008:75), ibu beranggapan ASI ibu kurang atau tidak memiliki cukup ASI, meniru teman, merasa ketinggalan jaman. Sehingga pada saat ini banyak ibu yang tidak memberikan ASI eksklusif kepada bayinya. (Heather, Welford, 2008:62)

Pada dasarnya dimasa pembangunan ini, menyusui bayi mempunyai arti ekonomi yang besar. Air susu ibu (ASI) harus dapat dianggap sebagai kekayaan nasional. Dari 150 juta jiwa penduduk Indonesia terdapat kira-kira 8 juta anak- anak usia dibawah 2 tahun. Bila seluruh bayi disusukan sampai Hubungan batin ibu dan bayi yang ditimbulkan oleh kontak kulit paling sensitif pada 12 jam pertama.Makin dini dan makin lama kontak bayi dan ibu, makin banyaklah produksi ASI Pijat oksitosin merupakan salah satu solusi untuk mengatasi ketidak cukupnya ASI. Pijat oksitosin adalah pemijatan pada sepanjang tulang belakang (vertebrae) sampai tulang costae kelima- keenam dan merupakan usaha untuk merangsang hormon prolaktin dan oksitosin setelah 
melahirkan (Biancuzzo, 2003; Indiyani, 2006; Yohmi \& Roesli, 2009). Pijatan ini berfungsi untuk meningkatkan hormon oksitosin yang dapat menenangkan ibu, sehingga ASI pun keluar. Penelitian yang dilakukan oleh Eko (2011) menunjukkan bahwa kombinasi tekhnik marmet dan pijat oksitosin dapat meningkatkan produksi ASI.

Hasil Studi pendahuluan yang telah dilakukan di Griya Sehat Mombykids sejak bulan Juli 2018 sampai bulan Desember 2018 tercatat ibu yang melahirkan normal berjumlah 195 dan semua ibu yang tidak terdapat kontra indikasi untuk menyusui, semua di ajari menyusui yang benar pada bayinya dan di beri penyuluhan tentang ASI esklusif. Dengan harapan semua ibu bisa memberikan ASI eksklusif pada bayinya, tetapi ketika saat kontrol hari ke 7, 50\% ibu sudah membawa botol dengan susu formula untuk bayinya. Dari semua ibu yang yang memberikan susu formula 50 $\%$ dengan alasan bahwa bayinya rewel karena ASI keluarnya sedikit. Dengan alasan ini maka perlu adanya intervensi agar bayi mendapatkan kecukupan ASI.

\section{BAHAN DAN METODE PENELITIAN}

Jenis penelitian menggunakan rancangan penelitian eksperimen semu atau quasy experiment dengan rancangan non randomized posttest without control group design. Penelitian eksperimen ini digunakan untuk mengukur pengaruh pijat oksitosin terhadap produksi ASI.

Populasinya adalah seluruh ibu post partum di Griya Sehat Mombykids pada bulan Januari - Maret tahun 2019 berjumlah 50 ibu post partum, sedangkan sampel berjumlah 50 orang. Pengambilan sampel dilakukan dengan metode purposive sampling.di bagi menjadi 2 kelompok yaitu 25 responden di lakukan intervensi pijat oxytocin dan 25 responden tidak. Kriteria sampel dalam penelitian ini adalah sebagai berikut: Ibu tidak sedang mengkonsumsi obat-obatan yang mempelancar pengeluaran ASI, ibu dan bayi dirawat dalam 1 ruangan (rawat gabung), bayi cukup bulan, dan bayi dengan berat badan lahir normal,bayi tidak diberikan susu formula ketika penelitian,bayi lahir dengan tidak ada cacat fisik dan refleks hisap bayibaik,Bayi tidak di tempatkan dalam ruangber AC.

Pengumpulan data menggunakan data primer dan sekunder dengan alat ukur hecklist. Analisis dilakukan mengunakan uji chisquare untuk mengetahui efektifitas dari pijat oksitosin.

Kerangka Konsep
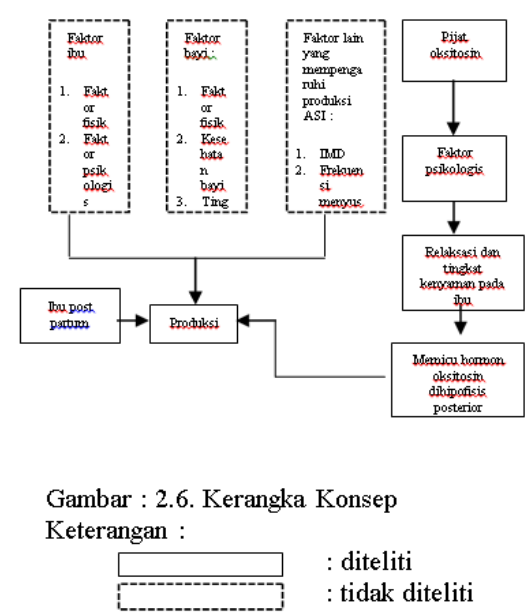

Berdasarkan tinjauan pustaka yang telah dijelaskan oleh Bobak (2005), Lawrence (2004), Perinasia (2004), Roesli (2002), Manuaba (2010).

Kerangka konsep diatas menjelaskan mengenai faktor-faktor penyebab ketidak lancaran proses laktasi meliputi faktor ibu (faktor fisik, faktor psikososial, faktor social budaya), faktor bayi (faktor fisik, kesehatan bayi, tingkah laku bayi), faktor lain yang mempengaruhi produk ASI (IMD, frekuensi menyusui, lamanya menyusui).

Pijat oksitosin dapat mempengaruhi faktor psikologis sehingga meningkatkan relaksasi dan tingkat kenyaman pada ibu, sehingga memicu produksi hormon oksitosin dan mempengaruhi produksi ASI. Efek pijat oksitosin adalah Sel kelenjar dipayudara mensekresikan ASI sehingga bayi mendapatkan ASI sesuai dengan kebutuhan yaitu berat badan bayi bertambah, urine bayi per - 24 jam 30- 
$50 \mathrm{mg}$ (6-8 kali), BAB bayi 2-5 kali, bayi tertidur selama 2-3 jam.Variabel bebas dalam penelitian ini adalah pijat oksitosin .Variabel terikat dalam penelitian ini adalah produksi ASI pada ibu post partum.

\section{PEMBAHASAN}

Berdasarkan hasil penelitian sebagian besar responden memiliki produksi ASI yang cukup dari padaresponden yang tidak cukup ASI. Produksi ASI yang cukup dapat dibuktikan dengan melihat produksi urin dan ketenangan bayi dalam 24 jam.

\begin{tabular}{|c|c|c|c|c|c|}
\hline \multirow[b]{2}{*}{ Pijat } & \multicolumn{5}{|c|}{ Produksi ASI } \\
\hline & Cukup & $\%$ & $\begin{array}{l}\text { Tidak } \\
\text { Cukup }\end{array}$ & $\%$ & umlah \% \\
\hline Pijat & 22 & 66,6 & 3 & 15,4 & 50 \\
\hline Tanpa Pijat & 10 & 33,4 & 15 & 84,6 & 50 \\
\hline Total & 32 & $100 \%$ & 18 & $100^{\circ}$ & $100 \%$ \\
\hline
\end{tabular}

Dalam penelitian ini untuk mengukur produksi ASI dapat dilakukan dengan melihat urin bayi baru lahir. Produksi urin bayi baru lahir dihitung selama 24 jam setelah ibu mendapatkan perlakuan pijat oksitosin. Hasil perhitungan didapatkan rata-rata produksi urin bayi baru lahir antara ibu yang mendapat perlakuan pijat oksitosin dan tidak medapatkan pijat oksitosin bebeda secara signifikan.

Penilaian produksi ASI bisa denganbanyak cara, salah satunya dengan mengukur dengan urin bayi selama 24 jam, normal volume urin bayi baru lahir $30-50 \mathrm{mg}$, atau bayi buang air kecil sebanyak 6-8 kali selama 24 jam, warna urin kuning jernih, jika ASI cukup setelah menyusu maka bayi tertidur atau tenang selama 2- 3 jam (Bobak, Perry \&Lowdermilk, 2005; Perinasia, 2004; Cox, 2006).

Efek terhadap produksi ASI,produksi ASI lebih banyak dan ASI keluar lancar lebih awal yaitu pada hari ke-2. Sedangakan responden yang tanpa dilakukan pijat oksitosin memiliki produksi ASI yang sedikit, meskipun ASI keluar namun ASI keluar lebih lama yaitu pada hari 3-4.

Mayoritas keseluruhan responden adalah umur antara 20-35 tahun (92\%). Menurut Biancuzo (2003) wanita dengan usia 20-35 tahun mempunyai produksi ASI lebih banyak dari pada Ibu-ibu yang usianya lebih 35 tahun, tetapi ibu- ibu yang sangat muda (kurang dari 20 tahun) produksi ASInya juga kurang banyak karena dilihat dari tingkat kematurannya.

Hasil penelitian Pudjiaji (2005) ibu-ibu yang berumur 19-23 tahun dibandingkan dengan ibu-ibu yang usianya lebih dari 35 tahun. Hasil penelitian ini diperkuat oleh Suraatmadja (2009) menyatakan bahwa ibu yang umurnya lebih muda lebih banyak memproduksi ASI dibandingkan dengan ibu yang lebih tua.

Hasil penelitian menunjukkan bahwa usia ibu terbanyak berada pada usia 20-35 tahun. Penjelasan diatas memberikan gambaran dalam penelitian ini bahwa ASI dipengaruhi usiaresponden.

Pengalaman menyusuhi sebelumnya jaga dapat mempengaruhi keberhasilan dalam pemberian ASI Esklusif. Pada ibu yang pertama kali hamil sehingga belum berpengalaman dalam pemberian ASI dan memungkinkan ibu tidak mengetahui halhal yang terkait dengan ASI. Pada penelitian ini paritas terbanyak pada ibu multipara sebanyak 28 responden $(70 \%)$, sehingga hal ini dapat mendukung kecukupan produki ASI bagi bayinya.

\section{KESIMPULAN}

Berdasarkan penelitian dan pembahasan mengenai efektivitas pijat oksitosin terhadap produksi ASI pada ibu nifas normal di Griya Sehat Mombykids Jombang, maka dapat diambil kesimpulan sebagai berikut :

1. Mayoritas produksi ASI pada ibu nifas di Griya Sehat Mombykids Jombang adalah cukup.

2. Ada perbedaan signifikan antara produksi ASI ibu nifas setelah mendapatkan pijat oksitosin dan tidak di Griya Sehat Mombykids Jombang.

\section{SARAN}

Berdasarkan hasil penelitian pijat oksitosin merupakan salah satu contoh intervensi 
mandiri bidan/perawat dan dapat dengan mudah dipilih dalampenatalaksanaan untuk merangsang produksi ASI. Masyarakat luas khususnya ibu post partum diharapkan mendapatkan pengetahuan dan informasi dalam upaya peningkatan produksi ASI serta dapat mengaplikasikan pijat oksitosin.

\section{DAFTAR PUSTAKA}

Arikunto, S. (2005). Manajemenpenelitian. Edisi Revisi. Jakarta : Rineka Cipta Budiati, T. (2009). Efektifitas pemberian paket "SUKSES ASI" terhadap produksi ASI ibu dengan sectiocaesarea. Tesis. Depok : FIK UI.

Cadwell, K. (2011). Buku saku manajemen laktasi. Jakarta :EGC

Dian, L. (2008). Hubungan pengetahuan laktasi dengan perawatan payudara pada ibu menyusui di rumah bersalin Seger Waras Surakarta. Surakarta : STIKES Kusuma Husada Direktorat Jenderal Bina Kesehatan Masyarakat. (2007). Pedoman penyelenggaraan pelatihan konseling menyusui dan pelatihan fasilitator konseling menyusui. Jakarta: Departemen Kesehatan

Nainggolan, M. (2009). Pengetahuan ibu primigravida mengenai faktor-faktor yang mempengaruhi kualitas dan kuantitas ASI di puskesmas Simalingkar Medan. Medan : Ilmu Keperawatan

Notoatmodjo. (2005). Metodologi penelitian kesehatan. Jakarta : PT Rineka Citra.

Nurmiati \& Besral. (2008). Pengaruh durasi pemberian ASI terhadap ketahanan hidup bayi di Indonesia . Makara, $12: 47-52$

Nursalam. (2008). Konsep dan penerapan metodologi ilmukeperawatan. Jakarta : MedikaSalemba.

Santjaka, A. (2009). Bio statistik.Purwokerto : Global Internusa.

Saryono. (2011). Metodologi penelitian keparawatan. Yogyakarta : Mitra Cendekia Press
Siregar, A. (2004). Pemberian ASI eksklusif dan faktor-faktor yang mempengaruhi. Medan : FKM USU.

Sugiyono. (2010). Statistik untuk penelitian. Bandung : CV. Alfabeta. 